University of Wollongong

Research Online

Faculty of Engineering - Papers (Archive)

Faculty of Engineering and Information

Sciences

$1-1-2005$

\title{
Human risk assessment of organic contaminants in reclaimed wastewater used for irrigation
}

S. Weber

Technical University of Aachen

Stuart Khan

University of Wollongong

J. Hollender

Technical University of Aachen

Follow this and additional works at: https://ro.uow.edu.au/engpapers

Part of the Engineering Commons

https://ro.uow.edu.au/engpapers/3466

\section{Recommended Citation}

Weber, S.; Khan, Stuart; and Hollender, J.: Human risk assessment of organic contaminants in reclaimed wastewater used for irrigation 2005, 724-735.

https://ro.uow.edu.au/engpapers/3466

Research Online is the open access institutional repository for the University of Wollongong. For further information contact the UOW Library: research-pubs@uow.edu.au 


\title{
Human Risk Assessment of Organic Contaminants in Reclaimed Wastewater used for Irrigation
}

\author{
S. Weber ${ }^{\mathrm{a}}$. S. Khan ${ }^{\mathrm{b}}$. J. Hollender ${ }^{\mathrm{a}^{\mathrm{at}}}$ \\ "Institute of Hygiene and Environmental Medicine. Technical University of Aachen. Germany. \\ Tel: +492418088282 . Fax +492418082477 . E-mail: Juliane. Hollenderapost mwh-iashen. ic. \\ Stelinie Wieberizipont.rutli-aachende \\ ${ }^{b}$ Environmental Engineering. University of Wollongong. NSW. 2522. Australia. \\ Tel: +6124221 3138. Fax + 6124221 3238, E-mail: slihancinow edu.aul \\ *Corresponding author
}

\begin{abstract}
Current water quality guidelines for reclaimed wastewater have predominantly addressed risks associated with the presence of microbial organisms. Comparatively, chemical parameters have been largely overlooked or inadequately considered. Acceptable levels of chemical parameters will be dependant on the proposed reuse applications for the water and, in many cases, site-specific factors such as the degree of dilution with water from other sources. However, some general principals for the determination of acceptable levels of chemical contaminants in reclaimed water may be applied universally. This study describes a general risk-assessment approach to the determination of acceptable contaminant concentrations. It provides some analysis of the principal functions of hazard identification, exposure assessment, dose-response relationship characterisation and risk characterisation as they relate to chemical contaminants in reclaimed water. Examples of some key modelling calculations for this process are provided for three selected contaminants (chloroform, 1,1,2-trichloroethane and pyrene) during hypothetical irrigation of agricultural area. Predicted environmental concentrations (PEC) are calculated and compared with predicted no effect concentrations (PNEC). The results of the hypothetical modelling exercise indicate that the contaminants considered in this theoretical analysis pose an acceptable risk to human health via the single exposure path consiclered (uptake through food grown in the irrigated soil).
\end{abstract}

Ǩywords: reclaimed wastewater irrigation, chemical risk assessment, fugacity modelling

\section{Introduction}

Throughout the last decade. municipal wastewater reuse has emerged as an important and viable means of supplementing dwindling water supplies in a large number of regions throughout the world. In many instances, reuse is also promoted as a means of limiting wastewater discharges to aquatic environments.

Health and environmental risks associated with water reuse have until now been addressed on a relatively uncoordinated ad hoc basis. Risks associated with microbial organisms have been addressed with the greatest urgency and are now dealt with in a thorough manner by guidelines used in many countries. Conversely, guidelines pertaining to chemical contaminants are typically limited to bulk parameters such chemical oxygen demand (COD), biochemical oxygen demand (BOD), pH and total suspended solids (TSS). In many situations these simple parameters provide suitable surrogate indications of the likely presence of chemical species of concern. However, for more highly treated reuse waters, they are of limited sensitivity. Furthermore. for some applications, an accurate assurance of specific chemical concentrations will be important. 
Some of the most thorough chemical guidelines have prescribed acceptable concentrations of some specific chemicals such as heavy metals, mineral oils. and some pesticides. Examples include those recently developed in Italy and Israel [1.2].

However. more recently emerging chemicals of concern. such as the endocrine disrupting chemicals (EDCs) and pharmaceutically active compounds (PhACs), are not specifically regulated by any current wastewater reuse guidelines of which we are aware. This situation is now on the very virge of change as scientists and regulators are grappling with how best to address the issues presented by a wide range of individual chemical contaminants.

Currently. there is very little analytical information available concerning the occurrence and fate of organic micropollutants during reuse applications so risk assessment must often be performed based on models. In the European Union environmental and human risk assessment is undertaken according to the Technical Guidance Document [3]. Quantitative chemical risk assessment approaches are anticipated to provide the most meaningful tools for most applications [4].

Many approaches to risk assessment of environmental chemicals have been proposed. but fundamental to all of them is the general concept of a risk quotient relating predicted environmental concentrations to predicted no-effect concentrations:

$$
\text { Risk Quotient }=\frac{\text { Predicted Environmental Concentration (PEC) }}{\text { Predicted No Effect Concentration (PNEC) }}
$$

The calculation of risk quotients is an essential step for the quantitative evaluation of risks from chemical exposure. In order to demonstrate acceptable risk to health or the environment, the PEC should be less than the PNEC. In other words. the risk quotient should be less than 1 .

It is proposed that a quantitative risk management system such as the 'Hazard Analysis at Critical Control Points (HACCP)' system would be most suitable for applications of wastewater reuse. The full details of a HACCP approach and analysis are well beyond the scope of this current study. However, some specific aspects pertaining to the presence and implications of chemical contaminants have been investigated and are described below.

Since one of the most important reuse applications concerning wastewater reclamation and human risk is the irrigation of agricultural land we have focused on such a scenario in this study. In order to evaluate risk quotients. PEC and PNEC have been determined for a hypothetical irrigation scheme. A highly simplified illustrative analysis was undertaken for a human risk assessment of three chemicals (chloroform. 1,1,2-trichloroethane and pyrene) in the irrigation wastewater.

\section{Hazard identification}

A wide range of trace chemical contaminants persist in municipal wastewaters after conventional treatment processes. A selection of such representative contaminants is given in Table 1. These include inorganic compounds. heavy metals, persistent organic pollutants, pesticides, disinfection byproducts, endocrine disrupters, pharmaceutically active compounds and complex-forming compounds. Many of these chemicals are known or suspected of deleterious implications to human health or the environment. 
Table 1 Reported occurrence of selected chemical pollutants in the environnent $[\mu \mathrm{g} / \mathrm{L}]$

\begin{tabular}{|c|c|c|c|c|c|c|}
\hline $\begin{array}{l}\text { Chemical } \\
\text { pollutant }\end{array}$ & $\begin{array}{l}\text { Influent STP: } \\
\text { Raw sewage water } \\
\text { (median) }\end{array}$ & $\begin{array}{l}\text { Emuent STP } \\
\text { (median) }\end{array}$ & $\begin{array}{l}\text { River water; } \\
\text { Surlace water } \\
\text { (median) }\end{array}$ & $\begin{array}{l}\text { Groundwater; } \\
\text { Bank filti'nte }\end{array}$ & $\begin{array}{l}\text { Soil } \\
\text { [Mg/kg] }\end{array}$ & ReI. \\
\hline$\overline{\mathrm{B}}$ & $500-3000$ & $3001-400$ & & & & {$[5]$} \\
\hline \multicolumn{7}{|l|}{ Henvy metals: } \\
\hline $\mathrm{Cr}$ & $1001-300]$ & & $0.2-650$ & $0.8-50$ & & [6] \\
\hline $\mathrm{Pb}$ & nd. -1000 & 1 & $0.2-1560$ & $z-100$ & & {$[6-\delta]$} \\
\hline $\mathrm{Hg}$ & $0.2-3$ & 28 & & & . & {$[6-8]$} \\
\hline \multicolumn{7}{|l|}{ PAH: } \\
\hline Pyrene & & & $\begin{array}{l}\text { n.d. }-10.33 \\
(0.05)\end{array}$ & & $\begin{array}{l}0.15-0.42 \\
2.5 \\
\text { n.d. }-6719^{b}\end{array}$ & {$[9-12]$} \\
\hline \multicolumn{7}{|l|}{ Pesticidles: } \\
\hline Diuron & & 0.62 & n.d. -0.43 & nd -0.004 & & {$[13,14]$} \\
\hline $2.4-\mathrm{D}$ & & 2.94 & n.d. -10.194 & & & {$[13.15]$} \\
\hline \multicolumn{7}{|l|}{ (herbıcide) } \\
\hline \multicolumn{7}{|c|}{ Organic solvents: } \\
\hline $\begin{array}{l}\text { 1.1.2-Trichloro- } \\
\text { ethane }\end{array}$ & & & $0.0104-0.9$ & & $\begin{array}{l}0,0001- \\
0,0014\end{array}$ & {$[16.17]$} \\
\hline \multicolumn{7}{|c|}{ Endocrine disrupting compounds: } \\
\hline Ethinylestradiol & $00.001-00100005)$ & $\begin{array}{l}=0.00013-0.004 \\
1000053\end{array}$ & n.d. -0.00004 & & & {$[18-20]$} \\
\hline \multicolumn{7}{|c|}{ Pharmace utically active compounds: } \\
\hline Diclofenac & $30.0 .47-1.9$ & n.d. -0.93 & n.d. -1.2 & n.d. -0.37 & & {$[21-24]$} \\
\hline Carbamazepine & 0.2: 1.7 & $0.1-2.1$ & $0.025-6.3$ & $0.9-1$ & & {$[21.25]$} \\
\hline Iopamidol & & $1.1 \pm 0.1$ & & $0.4 \cdot 1.4$ & & {$[24,26]$} \\
\hline \multicolumn{7}{|c|}{ Complex-forming compounds: } \\
\hline EDTA & & $700^{\circ 1}$ & $8.0-10$ & & & {$[13]$} \\
\hline \multicolumn{7}{|c|}{ Chlorination hyproducts: } \\
\hline $\begin{array}{l}\text { N-nitroso- } \\
\text { dime thylamine } \\
\text { (NDMA) }\end{array}$ & $\begin{array}{l}<0.001-0.009 \\
(<0.001)\end{array}$ & $\begin{array}{l}-0.001-0.063 \\
0.001)\end{array}$ & & & & {$[27]$} \\
\hline Chloroform & $1100^{d 3}$ & $\begin{array}{l}<1-20(3)^{e)} \\
106^{x i}\end{array}$ & n.d. $-3.8(0.5)^{e}$ & 198 & & {$[28,29]$} \\
\hline
\end{tabular}

Many inorganic species may be of particular concern for reuse applications involving irrigation of farmland. These may include salts of common ions such as sodium. potassium. calcium, chloride and bromide, as well as trace heavy metals including mercury and cadmium. Highly saline irrigation water can severely degrade soils over time and some compounds such as heavy metals may accumulate in soils. and later into foodstuffs. In dry climates. much of the irrigation water can evaporate and the concentration of salts in the drainage can be much higher than in the water itself, posing potential threats to groundwater quality [30]. Inorganic chemicals are among the most recalcitrant during most processes of wastewater treatment. They are often highly watersoluble and they are not susceptible to biological degradation. Similarly, advanced oxidation processes are ineffective and these small ions are among the most difficult contaminants to treat by membrane processes. For heavy metals, which have been included in some new and recommended giidelines [1,2], multi-element or multicomponent analysis determination methods like ICP-MS may simplify the required analytical effort.

An increasingly documented class of trace organic contaminants in wastewater are the "endocrine disnipting chemicals". Much attention has been devoted to natural and synthetic steroidal hormones, which are shown to induce biological effects on some organisms at part per trillion concentrations. Some steroidal hormones are poorly removed by conventional water treatment processes $[20,31]$. Other chemicals exhibiting similar effects at higher concentrations and known to be present in sewages include some plasticisers, pesticides and degradation products of some detergents. Further widespread attention has been focused on the broad range of pharmaceutically active compounds which have been reported in municipal wastewaters in many parts of 
the world [21-26]. At this point there are no indications for limitations to water reuse caused by these compounds. although their effects are largely unknown. Standardised methods for the analysis of these trace compounds are not generally available. but sophisticated analytical methods using GC-MS(MS) or LC-MS(MS) have been published in the scientific literature [18-21].

As in drinking water. byproducts of disinfection processes may yet prove to be among the greatest chemical concerns in recycled water. Recent attention in The USA and Canada has been given to the detection of the potent carcinogen. nitrosodimethylamine (NDMA) in chlorinated sewages. It is known that disinfection of wastewater effluents. especially those with relatively high organic loads, can lead to significant concentrations of NDMA [32.33].

For the illustrative study presented here, we have selected the model compounds chloroform. 1.1,2-trichloroethane and pyrene. Chlorinated solvents like trichloroethane are widely used in industrial processes and consequently can be found in the aqueous environment in the lower ng/L range [16]. Chloroform is also generated during water disinfection by the reaction of chlorine with humic compounds. Further production of chloroform can be initiated by reactions of strong oxidising agents and organic matter in the presence of chloride ion. Such conditions may arise from industrial effluents including those from pulp and paper manufacturing or the pharmaceutical industry [29]. The observed average chloroform concentration of US drinking water is approximately $13 \mu \mathrm{g} / \mathrm{L}$ [29]. Polycyclic aromatic hydrocarbons (PAH) such as pyrene are ubiquitous in the environment. They are produced mainly by incomplete combustion of organic matter such as wood, oil or coal. They are often one of the predominant contaminants in sediments and soils at concentrations in the upper $\mu \mathrm{g} / \mathrm{kg}$ range [34]. We selected these well-known compounds for evaluating the risk models because (1) their toxic effects are known. (2) our estimations can be compared with observed concentrations in the environment and (3) they include a range of the important plysical-chemical properties required by the models. The two cllorinated compounds are similarly lipophilic (Log $\mathrm{K}_{\text {ow }}$ ), but chloroform lias a greater water solubility and is more volatile than 1,1.2trichloroethane. In contrast pyrene is many orders of magnitude less volatile and largely insoluble in water.

\section{Exposure Assessment}

An essential component of any chemical risk assessment processes must be a means of determining or estimating levels of exposure. This requires a qualitative analysis of routes of exposure of a chemical to the target organism as well as quantitative information such as the concentration of target chemicals in relevant media. For preventative risk assessment, both aspects inevitably require some degree of prediction.

The first step of qualitative human exposure assessment will be to identify likely and potential routes of exposure of the chemicals to humans. This will determine the significance of chemical concentrations in environmental media such as soil. air or water. For irrigation of agricultural land with reclaimed wastewater, four major anticipated pathways of exposure are shown in Table 2. This is a simplified list since. for example. it does not include additional exposure routes which may be significant for people working directly with the irrigation scheme. 
Table 2. Possible exposure pathways of chemicals to humans via agricultural irrigation

\begin{tabular}{ll}
\hline Pathway & Scenario \\
\hline - Reclaimed water irrigation $\rightarrow$ soil $\rightarrow$ plant & - Ingestion of food plants cultivated on land \\
uptake $\rightarrow$ food production $\rightarrow$ human toxicity & irrigated with reclaimed water \\
- Reclaimed water irrigation $\rightarrow$ soil $\rightarrow$ plant & - Ingestion of meat/animal products from animals \\
uptake $\rightarrow$ animal uptake $\rightarrow$ lruman toxicity & pasture on land irrigated with reclaimed water \\
- Reclaimed water irrigation $\rightarrow$ soil $\rightarrow$ vadoze & - Ingestion of drinking water produced from \\
zone $\rightarrow$ groundwater $\rightarrow$ human toxicity & groundwater polluted by reclaimed water \\
- Reclaimed water irrigation $\rightarrow$ atmosphere $\rightarrow$ & - Inlialation of volatile contaminants during \\
luman toxicitv & irrigation process \\
\hline
\end{tabular}

In individual cases. it will be necessary to make initial judgements regarding the significance of each identified exposure route. In this example we focus on the first pathway. shown schematically in Figure 1. It will be the environmental concentrations in the soil matrix that are of greatest significance to this case. Accordingly. PEC and PNEC will be determined for the soil matrix.

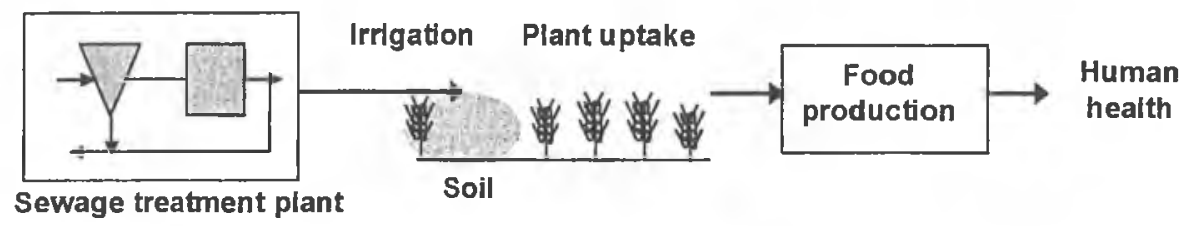

Figure 1 Prinary exposure pathway of chemicals to humans via agricultural irrigation

\section{Predicted Environmental Concentrations}

One approach to establishing PEC is the use of fugacity modelling techniques. In the absence of comprehensive quantitative analytical data. fugacity calculations can provide useful estimations of overall fate and behaviour of individual chemical components. Although such techniques are limited by the availability of high-quality site-specific input data. they represent a valuable tool for the broad evaluation of the distribution and removal of chemicals during water treatment. storage and reuse applications.

Environmental fugacity-based models have largely been developed over the last 25 years $[35,36]$. These models rely on defined environmental compartments such as air, water. soil etc. By equating the fugacity or "escaping tendency" of a chemical in each of the compartments. an environmental distribution is calculated. Variable removal processes such as advection or degradation provide determinations of final concentrations among the defined compartments.

Here we provide an illustration of how fugacity modelling may be used to predict the fate of organic chemicals in water reuse applications. Various "Levels" of fugacity models have been described. ranging in complexity from Level 1 to Level 4 . It is considered that a Level 3 model is most suitable for the current application. The Level 3 model provides predictions of steady-state. non-equilibrium concentrations and distributions of environmental contaminants.

The liypothetical irrigated property consisted of a rectangular field of dimensions $450 \mathrm{~m} \times 400 \mathrm{~m}$. A $25 \mathrm{~m}$ wide waterway ran along one of the two $400 \mathrm{~m}$ boundaries. thus the overall area of the property including the irrigated soil and the waterway was $190,000 \mathrm{~m}^{2}$. The average depth of the waterway was $10 \mathrm{~m}$. The water compartment was composed of water, suspended sediment ( $2 \%$ organic carbon) and aquatic biota ( $5 \%$ lipid). The atmospheric depth was modelled as $1000 \mathrm{~m}$ and was composed of air and 
aerosols. The soil compartment was composed of air, water and solids comprising $2 \%$ organic carbon. Soil was presumed to be well mixed to a depth of $10 \mathrm{~cm}$. The sediment on the floor of the waterway comprised water and solids ( $4 \%$ organic carbon) and was mixed to a depth of $5 \mathrm{~cm}$. The organic fractions and densities of all components were selected as recommended by Mackay et al [36]. Advective flow of air out of the modelled region was set at $10^{6} \mathrm{~m}^{3} / \mathrm{h}$. Advective removal by the waterway was $200 \mathrm{~m}^{3} / \mathrm{h}$. Burial by sediment was also treated as an advective loss and was modelled at 0.002 $\mathrm{m}^{3} / \mathrm{h}$. Full details of the environmental parameters are provided in Table 3.

Table 3. Compartment dimensions and properties for field irrigation

\begin{tabular}{llllllll}
\hline & Conipartment & $\begin{array}{c}\text { Depth } \\
(\mathrm{m})\end{array}$ & $\begin{array}{c}\text { Area } \\
\left(\mathrm{m}^{2}\right)\end{array}$ & $\begin{array}{c}\text { Volume } \\
\left(\mathrm{m}^{3}\right)\end{array}$ & $\begin{array}{c}\text { Organic } \\
\text { fraction }\end{array}$ & $\begin{array}{c}\text { Density } \\
\left(\mathrm{kg} . \mathrm{m}^{-3}\right)\end{array}$ & $\begin{array}{c}\text { Advective } \\
\text { flow }\left(\mathrm{m}^{3} / \mathrm{h}_{1}\right)\end{array}$ \\
\hline \multirow{3}{*}{ Air } & Total compartment & 1000 & $2 \times 10^{5}$ & $2 \times 10^{8}$ & - & 1.2 & $10^{6}$ \\
& Air & & & $2 \times 10^{8}$ & - & 1.2 & $10^{6}$ \\
& Aerosol & & & $2 \times 10^{-3}$ & - & 2000 & $10^{6}$ \\
\hline \multirow{4}{*}{ Water } & Total compartment & 10 & $10^{4}$ & $10^{5}$ & - & 1000 & 200 \\
& Water & & & $10^{5}$ & - & 1000 & 200 \\
& Suspended sediment & & & 10 & 0.02 & 1500 & 200 \\
& Aquatic biota & & & 0.2 & 0.051 lipid & 1000 & 200 \\
\hline \multirow{4}{*}{ Soil } & Total compartment & 0.1 & $18 \times 10^{4}$ & $18 \times 10^{3}$ & - & 1500 & - \\
& Air & & & $3.6 \times 10^{3}$ & - & 1.2 & - \\
& Water & & & $5.4 \times 10^{3}$ & - & 1000 & - \\
& Solid & & & $9 \times 10^{3}$ & 0.02 & 2400 & - \\
\hline \multirow{3}{*}{ Sediment } & Total compartment & 0.05 & $10^{4}$ & 500 & - & 1280 & 0.002 \\
& Water & & & 400 & - & 1000 & 0.002 \\
& Solid & & & 100 & 0.04 & 2400 & 0.002 \\
\hline
\end{tabular}

The field was assumed to be irrigated at an average of $700 \mathrm{~mm}$ per year over the entire surface area. The three contaminants were each presumed to be present in the treated effluent at a concentration of $10 \mathrm{ng} / \mathrm{L}$. Therefore the total application of each chemical to the field was $1.26 \mathrm{~g}$ per year. The physical properties of the contaminants are provided in Table 4. These data are all extracted from the experimental database packaged with the EPI Suite software package, except for the BIOWIN and AOPWIN values which are predicted values from the same software [37].

Table 4. Properties of modelled contaminants from EPI Suite [37]

\begin{tabular}{lccc}
\hline Chemical Name: & chloroform & 1.1.2-trichloroethane & pyrene \\
\hline Molecular Weight $\left(\mathrm{g} \cdot \mathrm{mol}^{-1}\right):$ & 119.38 & 133.41 & 202.26 \\
Aqueous Solubility $\left({\left.\mathrm{g} \cdot \mathrm{m}^{-3}\right):}\right.$ & 7950 & 4590 & 0.135 \\
Log Kow: & 1.97 & 1.89 & 4.88 \\
melting point $\left({ }^{\circ} \mathrm{C}\right):$ & -63.6 & -36.6 & 151.2 \\
vapour pressure $(\mathrm{Pa}):$ & $2.6 \times 10^{4}$ & $3.1 \times 10^{3}$ & $6.0 \times 10^{-4}$ \\
BIOWIN4 & 3.3737 & 3.3534 & 2.8537 \\
AOPWIN half-life $(\mathrm{l})$ & 1206 & 561 & 3 \\
\hline
\end{tabular}

Environmental biodegradation rates typically represent the greatest obstacle to reliable modelling. This is due to a general lack of information regarding degradation of specific compounds in various environmental media. as well as the extreme variation that can result from seemingly subtle environmental variations. Consequently, there are no highly reliable methods of predicting environmental biodegradation. A "best available" method has previously been described for extrapolating predicted "BIOWNN4" data for use in fugacity modelling [38]. We have used an analogous relationship to determine approximate biodegradation half lives in water: Half-life in 
water $(\mathrm{h})=10^{(6-\text { BIOWDN4 value) }}$. Following the typical variations of degradation rates among phases described by Mackay et al [36]. average half-lives in soil and sediment were approximated by multiplying the half-life in water by factors of 2 and 10 respectively. Half-lives in air were estimated by AOPWIN, Data derived by these processes should be considered only as reasonable estimates of the order-of-magnitudes. Level 3 fugacity calculations were undertaken as previously described [36]. Key summary data are provided graphically for chloroform. 1.1.2-trichloroethane and pyrene.

Figure 2 shows the relative distributions of each of the contaminants among the modelled phases. Chloroform is a highly volatile chemical and was thus predicted to partition significantly $(95 \%)$ to the air phase. The vast majority of the remainder of this contaminant is partitioned to the soil phase. 1.1.2-trichloroethane is less volatile than chloroform and only $79 \%$ of the steady-state mass was predicted in the air phase. $20 \%$ was in soil and $1 \%$ in water. The most extreme results were predicted for pyrene which is non-volatile and highly hydrophobic. Pyrene was predicted to be partitioned exclusively to soil.
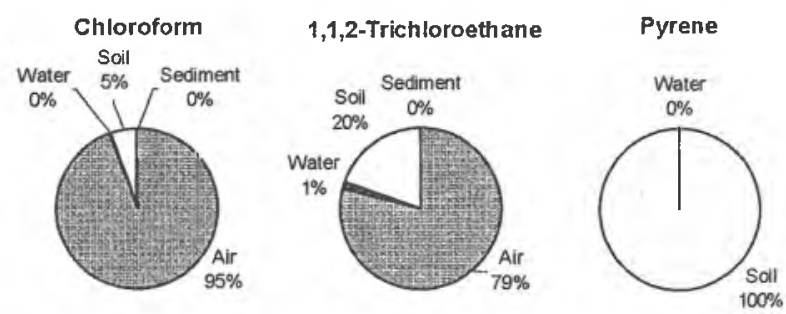

Figure 2. Relative distribution of three contaminants among modelled phases

As shown in Figure 2, the predicted relative amount of 1,1.2-trichloroethane in soil is about one fifth of the relative amount of pyrene in soil. However, the predicted absolute steady-state mass of 1.1.2-trichloroethane in soil is only about $4 \%$ the predicted absolute steady-state mass of pyrene in soil (see Fig. 3). This is because, pyrene is not removed from the overall system as efficiently as 1,1,2-trichloroethane or chloroform.

There are seven possible removal mechanisms for each of the chemicals: degradation in each of the four phases, advection from water or air. and burial by sediment. Pyrene was predicted to be the least biodegradable of the contaminants, but it was also the least susceptible to advection since it is partitioned exclusively to soil. from which no advection occurs. Furthermore. although pyrene was predicted to have a relatively short degradation half life in air. this was not significant since pyrene was not appreciably partitioned to air. It was a combination of these effects that lead to the relative accumulation of pyrene.

Figure 3 is presented in Log scale to clearly display the extreme variations in steady-state concentrations of the contaminants among the principal phases of air. water, soil and sediment. Given the considerable partitioning of chloroforn to air (Figure 2), it may at first be surprising to note the relatively low concentration of this compound in this phase. The explanation is that the volume of the air phase $\left(2 \times 10^{8} \mathrm{~m}^{3}\right)$ is numerous orders of magnitude greater than the volume of any of the other phases. Hence. air can accommodate substantially more of a compound without building up high concentrations. The opposite extreme of this effect was observed for sediment. Although none of the contaminants were predicted to partition significantly to sediment 
(Figure 2), all three were predicted in sediment at moderate concentrations. Again. the explanation is that even when sediment is heavily concentrated with contaminant, the small volume of sediment requires only a relatively minor fraction of the overall contaminant to achieve this. As shown in Figure 3, chloroform was predicted in the irrigated soil at around $+\times 10^{1} \mathrm{ng} / \mathrm{m}^{3} .1,1,2$-trichloroethane at $1 \times 10^{2} \mathrm{ng} / \mathrm{m}^{3}$ and pyrene at $3 \times 10^{3} \mathrm{ng} / \mathrm{m}^{3}$.

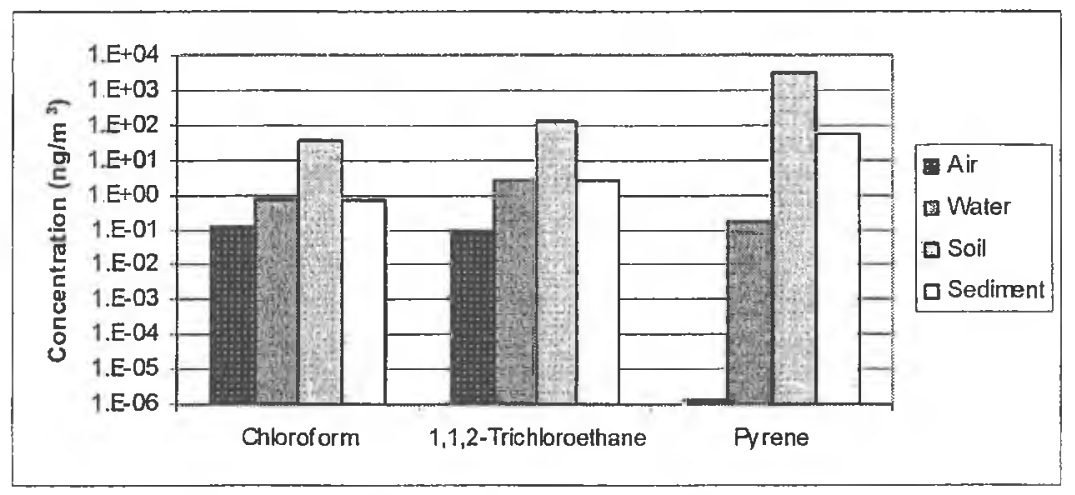

Figure 3. Steady-state concentrations of contaminants among phases

\section{Predicted No Effect Concentrations}

Toxicity of chemicals to an organism is normally defined in terms of doseresponse relationships. When the target organisms are luumans. dose-response relationships may be derived from data obtained in epidemiological investigations. extrapolations from animal studies. or toxicity assays on mammalian or bacterial cells. Epidemiological data can provide the most realistic cause-effect relationships. but are only available for a very limited number of chemicals. The long latency period of disorders caused by environmental toxicants, such as cancer. reduces the quality of the data by hindering the determination of the effects. Dose-response relationships. once established. may then be used to derive an "acceptable daily intake" (ADI) for each specific chemical, usually with the application of safety factors to account for any uncertainty. Finally, established ADI values can be used to determine environmental PNEC.

A simple theoretical model has been developed for the estimation of the maximum permissible soil pollutant concentration based on toxicological data $[8,39]$. It is useful to determine the maximum soil pollutant concentration instead of a wastewater concentration because the wastewater composition may be highly fluctuating and accumulation of contaminants takes place in the soil phase. The values obtained from this model may be applied as the PNEC of a specific chemical. The model is used to calculate a maximum allowed soil pollutant concentrations $\mathrm{Cs}(\mathrm{mg} / \mathrm{kg})$ from a chemical's $A D I$ in milligrams per kilogram of body weight (BW) per day $[8,39]$ :

$$
\mathrm{Cs}(\mathrm{mg} / \mathrm{kg})=\frac{\mathrm{ADI}(\mathrm{mg} / \mathrm{kgBW} / \mathrm{day}) \times 60(\mathrm{kgBW}) \times \mathrm{B}}{\sum\left[\mathrm{I}_{\mathrm{i}} \times \mathrm{f}_{\mathrm{i}} \times \mathrm{K}_{\text {spi }} \times \mathrm{FD}_{\mathrm{i}}\right]}
$$

The additional parameters of this equation include an index (i) representing the food groups grain/cereal, vegetable, root/tuber, and fruit: a daily consumption rate $\left(I_{i}\right)$ of ith food group: the fraction $\left(f_{i}\right)$ of ith food group affected by land application: a 
plant/soil partition factor $\left(\mathrm{K}_{\text {spi }}\right)$ for ith food group: and a fresh weight to dry weight conversion factor $\left(F D_{1}\right)$ for ith food group. The model assumes that pollutant exposure (background plus land-application induced) from the consumption of these crops is limited to $50 \%$ of the total ADI. To account for this, a coefficient of background exposures (B) is applied and set to 0.5 .

In this analysis we have applied the values for the constant parameters as those previously recommended by Cheng et al [8, 39]. We have also applied the method suggested by them for the estimation of plant/soil partition factors ( $\log \mathrm{Ksp}=1.588-$ $0.578 \times$ Log Kow) [8. 39].

As a worst-case scenario. the hypothetical exposure in this study was represented by the food chain exposure of an adult $(60 \mathrm{~kg})$ whose entire dietary intakes of grain/cereal. vegetable. root/tuber. and fruit are derived from food plants grown in reclaimed water-irrigated soils. For each of the modelled chemicals. the ADI waS selected as the published reference dose (RfD) from the US-EPA Integrated Risk Information System (IRIS) [40]. The soil concentrations calculated from this model are given in Table 5 as PNEC.

Table 5. PNEC established by modelling from reported reference doses (RfD).

\begin{tabular}{lcc}
\hline Organic compound & RfD $(m g / k g / d)[40]$ & PNEC $(\mathrm{mg} / \mathrm{kg})$ \\
\hline Chloroform & 0.01 & $2 \times 10^{-1}$ \\
Pyrene & 0.03 & $3 \times 10^{1}$ \\
1.1.2-Trichloroethane & 0.004 & $9 \times 10^{-2}$ \\
\hline
\end{tabular}

The calculated PNEC values are significantly greater reported average soil concentrations (see Table 1). It is important to emphasise that the PNEC values calculated here are based purely on human toxicological implication and do not consider potential environmental impacts. Furthermore. there is a lack of supporting subchronic. chronic and reproductive studies data. which reduces the confidence in the resulting $\mathrm{RfD}$ value used in this simple model.

\section{Conclusion}

The exposure assessment indicates that during reclaimed water irrigation the selected organic model contaminants would accumulate in varying degrees in the soil of the irrigated property. Accordingly. the uptake of the chemicals to food grown in the soil will be an important exposure route for human risk assessment.

Calculation of risk quotients can be undertaken. for each of the three chemicals in the hypothetical study, from the determined values of PEC and PNEC. By adjusting the soil PEC values from Section 4 and the PNEC from Section 5 to the same units, a risk quotient can be calculated for each of the three contaminants. The risk quotients then are chloroform $\left(10^{-7}\right)$, pyrene $\left(10^{-7}\right)$ and $1.1,2$-trichloroethane $\left(10^{-6}\right)$.

In such a scenario, the risk quotients for all three chemicals would be acceptably low for human health effects via the uptake from food. While the risk quotients would be acceptable, the high degree of uncertainty in the modelling processes would indicate the strong desirability for analytical confirmation including a monitoring program throughout numerous stages of the agricultural irrigation scheme. A further high degree of uncertainty emanates from the unavailability of comprehensive data for selection of appropriate $\mathrm{ADI}$ or $\mathrm{RfD}$ values. In particular. data for chronic, subchronic and reproductive effects are not sufficiently available. For many compounds ADI and RfD values are not available at all. 
In cases where unacceptably high risk quotients are predicted. modifications to the intended water reuse strategy will be necessary. Such modifications could include more effective treatment of the water prior to irrigation: a decrease in the amount of reclaimed water to be used on the property: or a change in the choice of crops to be grown.

This study has presented an illustrative analysis of a highly simplified hypothetical wastewater reuse application. Nonetheless, it has successfully demonstrated the general concepts of an approach to chemical risk assessment that, with refinement. should be highly applicable to a very wide variety of circumstances. While the procedure does rely on a certain amount of real input data for a particular system. it will be possible for judiciously selected 'typical' values to be used for many parameters in real risk assessment cases. This is because the final values predicted by the models will not always be highly sensitive to all of the modelled parameters.

Finally. risk assessment of chemicals regarding wastewater reuse will. in many cases. need to be undertaken with respect to environmental organisms. as well as lumans. Consequently. a wide variety of PNEC techniques will be required. In practice. the number of analyses can be minimised by undertaking risk assessments for "worst case scenarios'. This may be achieved by identifying the most highly susceptible organisms which are affected in the reuse application and calculating PNEC values solely on the basis of those organisms.

\section{References}

1. Anonymous. Quality criteria for reuse of reclaimed water for unrestricted irrigation and disposal to river bodies in Israel. 2003. Inbar Committee.

2. Ministero dell' Amiente e della Tutela del Territorio. Regolamento recante norme techniche per il riutilizzo delle acque reflue. Decree 12 giugno $2003, \mathrm{n}$. 185. 2003. Rome.

3. Commission of the European Communities and European Chemicals Bureau. Technical guidance document in support of the Commission Directive 93/67/EEC on risk assessment for new notified substances and Commission Regulation (EEC) No. 1488/94 on risk assessment for existing substances. 1996. Ispra. Italy.

4. Hoornstra. E.. M.D. Northolt. S. Notermans and A.W. Barendsz. The use of quantitative risk assessment in HACCP. Food Control, 12 (2001) 229-234.

5. Mekorot. Israel National Water Co. Dan Region Project- Groundwater Recharge with Municipal water. 2003.

6. Olivieri. A.W.. D.M. Eisenberg, R.C. Cooper. G. Tchobanoglous and P. Gagliardo. Recycled water - A source of potable water: City of San Diego health effects study. Water Sci. Technol. 33 (1996) 285-296.

7. Mujeriego. R. and T. Asano. The role of advanced treatment in wastewater reclamation and reuse. Water Sci. Technol., 40 (1999) 1-9.

8. Chang, A.C.. P. Genexing, A.L. Page and T. Asano. Developing Human Healthrelated Chemical Guidelines for Reclaimed Water and Sewage Sludge Applications in Agriculture. 2001, Geneva. World Health Organization.

9. European Commission. Joint Research Centre. Institute for Environment and Sustainability. Soil and Waste Unit. UMEG Center for Environmental Measurements. Environmental Inventories and Product Safety. Organic contaminants in sewage sludge for agricultural use. 2001. 
10. Long, J.L.A., W.A. House. A. Parker and J.E. Rae. Micro-organic compounds associated with sediments in the Humber rivers. Sci. Total Environ. . 210-211 (1998) 229-253.

11. Motelay-Massei. A., D. Ollivon. B. Garban. M.J. Teil. M. Blanchard and M. Chevreuil. Distribution and spatial trends of PAHs and PCBs in soils in the Seine River basin. France. Chemosphere, 55 (2004) 555-565.

12. Nadal. M. . M. Schuhnacher and J.L. Domingo. Levels of PAHs in soil and vegetation samples from Tarragona County. Spain Einviron. Pollut., 132 (2004) $1-11$.

13. Knepper. T.P., D. Barcelo. K. Lindner, P. Seel, T. Reemtsma, F. Ventura, H. De Wever, E. van der Voet. P. Gehringer and M. Schonerklee. Removal of persistent polar pollutants through improved treatment of wastewater effluents (P-THREE). Water Sci. Technol., 50 (2004) 195-202.

14. Rodriguez-Mozaz. S.. M.J.L. de Alda and D. Barcelo. Monitoring of estrogens. pesticides and bisphenol $\mathrm{A}$ in natural waters and drinking water treatment plants by solid-phase extraction-liquid chromatography-mass spectrometry. $J$ Chromatogr.4. 1045 (2004) 85-92.

15. Vassilakis. I.. D. Tsipi and M. Scoullos. Determination of a variety of chemical classes of pesticides in surface and ground waters by off-line solid-phase extraction. gas chromatography with electron-capture and nitrogen-phosphorus detection, and high-performance liquid chromatography with post-column derivatization and fluorescence detection. J Chromatogr A, 823 (1998) 49-58.

16. McCulloch. A. Trichloroacetic acid in the environment. Chemosphere, 47 (2002) 667-86.

17. Altissimo. L.. E. Andreoli, A. Giacometti and A. Marcomini. Time trends of 1.1.1-trichloroethane, triclloroethylene, and perchloroethylene in confined and unconfined aquifers of a groundwater system in northern Italy. Ann Chim, 92 (2002) 61-71.

18. Baronti. C., R. Curini, G. D'Ascenzo, A. Di Corcia. A. Gentili and R. and Samperi. Monitoring Natural and Synthetic Estrogens at Activated Sludge Sewage Treatment Plants and in a Receiving River Water. Environ. Sci. Technol., 34 (2000) 5059-5066.

19. Ternes, T.A.. H. Andersen, D. Gilberg and M. Bonerz. Determination of estrogens in sludge and sediments by liquid extraction and GC/MS/MS. Anal. Chem., 74 (2002) 3498-3504.

20. Zülllke, S., U. Dünnbier, T. Heberer and B. Fritz. Analysis of endocrine disrupting steroids: Investigation of their release into the environment and their behavior during bank filtration. Ground Water Monit. R, 24 (2004) 78-85.

21. Heberer, T. Occurrence fate, and removal of pharmaceutical residues in the aquatic environment: a review of recent research data. Toxicol. Lett., 131 (2002) 5-17.

22. Buser, H.R., T. Poiger and M.D. Muller. Occurrence and fate of the pharmaceutical drug diclofenac in surface waters: Rapid photodegradation in a lake. Environ. Sci. Technol., 32 (1998) 3449-3456.

23. Hilton, M.J. and K.V. Thomas. Determination of selected human pharmaceutical compounds in effluent and surface water samples by high-performance liquid chromatography-electrospray tandem mass spectrometry. J Chromatogr .4 .1015 (2003) 129-141. 
24. Ternes, T.A., J. Stuber, N. Herrmann. D. McDowell. A. Ried. M. Kampmann and $\mathrm{B}$. Teiser. Ozonation: a tool for removal of pharmaceuticals. contrast media and musk fragrances from wastewater? Water Res. 37 (2003) 1976-82.

25. Clara. M.. B. Strenn and N. Kreuzinger. Carbamazepine as a possible anthropogenic marker in the aquatic environment: investigations on the behaviour of Carbamazepine in wastewater treatment and during groundwater infiltration. Water Res., 38 (2004) 947-54.

26. Rohweder. U. Ergebnisse des Untersuchungsprogramms "Arzneimittel in der Umwelt". Bericht an die 61. Unweltministerkonferenz am 19./20.11.2003 in Hamburg. Untersuchungen im Auftrag des Bund/Länderausschusses für Chemikaliensicherheit (BLAC). 2003. Freie und Hansestadt Hamburg. Behörde für Umwelt und Gesundheit.

27. Inquiry Centre at Environment Canada. Assessment Report N-Nitrosodimethylamine. 2002. Quebec. Canada.

28. Egorov, A.I.. A.A. Tereschenko. L.M. Altshul. T. Vartiainen. D. Samsonov. B. LaBrecque. J. Maki-Paakkanen. N.L. Drizhd and T.E. Ford. Exposures to drinking water chlorination by-products in a Russian city. Int J Hyg Environ Health, 206 (2003) 539-51.

29. McCulloch. A. Chloroform in the environment: occurrence. sources. sinks and effects. Chemosphere, 50 (2003) 1291-1308.

30. Bouwer, H. Groundwater problems caused by irrigation with sewage effluent. $J$. Environ. Health. 63 (2000) 17-20.

31. D'Ascenzo, G.. A. Di Corcia. A. Gentili. R. Mancini. R. Mastropasqua, M. Nazzari and R. Samperi. Fate of natural estrogen conjugates in municipal sewage transport and treatment facilities. Sci. Total Environ. 302 (2003) 199209.

32. Mitch. W.A. and D.L. Sedlak. Characterization and fate of N-nitroso-dimethylamine precursors in municipal wastewater treatment plants. Environ. Sci. Technol, 38 (2004) 1445-54.

33. Mitch, W.A.. A.C. Gerecke and D.L. Sedlak. A N-Nitrosodimethylamine (NDMA) precursor analysis for chlorination of water and wastewater. Water Res., 37 (2003) 3733-41.

34. Koh. C.H., J.S. Khim, D.L. Villeneuve, K. Kannan and J.P. Giesy. Analysis of trace organic contaminants in sediment. pore water. and water samples from Onsan Bay, Korea: instrumental analysis and in vitro gene expression assay. Environ. Toxicol. Chem., 21 (2002) 1796-803.

35. Mackay. D. and S. Paterson. Evaluating the Multimedia Fate of Organic Chemicals - a Level-III Fugacity Model. Environ. Sci. Technol. 25 (1991) 427436.

36. Mackay. D.. W.-Y.S. and and K.-C. Ma. Illustrated Handbook of PhysicalChemical Properties and Environmental Fate for Organic Chemicals. V. 1997. Florida. Lewis Publishers.

37. US EPA. EPI Suite (v. 3.12). 2000.

38. Khan. S.J. and J.E. Ongerth. Modelling of prescription pharmaceutical residues in Australian sewage based on quantities of use and fugacity calculations. Chemosphere. 54 (2004) 355-367.

39. Chang, A.C.. A.L. Page, T. Asano and I. Hespanhol. Developing human healthrelated chemical guidelines for reclaimed wastewater irrigation. Water Sci. Technol. 33 (10-11) (1996) 463-472.

40. US EPA. Integrated Risk Information System (IRIS). http://www.epa.gov/iris/ 